\title{
Specifics of agricultural sector state support: domestic and foreign experience
}

\author{
Marina Kholodova ${ }^{1, *}$, Mikhail Kabanenko ${ }^{1}$, Tatiana Kushnarenko ${ }^{2}$, Lyudmila Dubrova $^{2}$ and \\ Raykhana Bulatova ${ }^{3}$ \\ ${ }^{1}$ The Federal agrarian scientific center of Rostov, All-Russian Research Institute of Economics and \\ Standards, 41, st. Chehova, 344006, Rostov-on-Don, Russia \\ ${ }^{2}$ Don State Technical University, 1, pl. Gagarina, 344002, Rostov-on-Don, Russia \\ ${ }^{3}$ Rostov State University of Economics (RSUE), 69, st. Bolshaya Sadovaya, 344002, Rostov-on-Don, \\ Russia
}

\begin{abstract}
The comparative analysis of agriculture state support in Russia and world's top economies is conducted in the article. Some aspects of transformation of the national state support system of agricultural sector are studied. The methodology of the stated problem research is built upon the system of general scientific and local methods and techniques. The information-analytical basis of the study includes the data of the Ministry of Agriculture, the data of the Federal State Statistics Service of Russian Federation and agricultural statistical data of the Organization for Economic Cooperation and Development (OECD). The assessment of the level of agricultural production state support in Russia is carried out in the article. The in-depth comprehensive economic analysis of financial structure of the updated areas of the State Program for agricultural development in Russia is performed. It is proved that in line with the consolidation of state support actions regarding the disposition of the "united subsidy", the regional authorities managed to identify and significantly expand the priority areas of the industry development.
\end{abstract}

\section{Introduction}

At present time, each and every economic power can not manage without the state support of agricultural production. The distinguishing feature of such countries is the specification of state regulation procedures which depend on the level of agricultural development and national priorities.

The contemporary state policy of economic powers requires transformation of the relations between state and market regulation, direct and indirect methods of agriculture support in favour of the last ones to achieve the enhancement of efficiency and competitiveness of the industry, wise utilization of resources and well-balanced agricultural market conjuncture [1]. The relative and sometimes absolute reduction of government expenditures for financing the agricultural sector of economy is currently driven by the increase of the agricultural policy efficiency, in common, under the conditions of the battle

* Corresponding author: kholodovama@ rambler.ru 
for world leadership, followed by the introduction of sanctions regimes.

\section{Research methodology}

The research methodology is based on the system of fundamental and specialized scientific methods. The study of national and foreign experience of agricultural sector support is based on the system of principles (development, determinism, unity and diversity of the studied processes and phenomena) and methods (observation, abstraction, synthesis, analysis, deduction, induction and comparison). Methods of contemporary economic theory (system, evolutionary, institutional and statistical analysis) are used to investigate the agricultural sector state support.

The research information basis includes official statistics data of Russian Federation and international organizations along with the research results, contained in monographies, papers of Russian and foreign economists, periodical articles.

\section{Results}

Agriculture as one of the vitally important economic sectors serves not only to provide food security and state economic independence, but also to achieve higher living standards of the nation (length of life, working capability of the population, health of the nation, demographic situation in the country), as well as to build conductive conditions for support industries development by the process of interbranch connections expansion.

In this regard, special attention should be paid to the state support of the rural sector of the economy, including Russian experience, in the context of contemporary world economic conditions. The global experience of economic transitions shows that the state should be actively involved in settlement of such problems as import substitution, instability of the internal and external environment of the sector development, low level of its investment activity and high risks of business and operations.

According to the study, Russia lags far behind economically developed countries by the level of state support of agricultural production in absolute terms. Thus, in 2018 this index number amounted to 5158 billion US dollars in Russia, while in China -110940 billion US dollars, in the EU - 99887 billion US dollars, in the United States - 85288 billion US dollars. [2]

While studying the global experience of agricultural production support, let us consider countries with highly competitive agricultural industry and oversaturated agricultural market. For instance, the decrease in the share of producer support (PSE) in the aggregate amount of income is observed in the US and the EU, due to indirect methods - price support and direct methods - subsidization (Figure 1). 


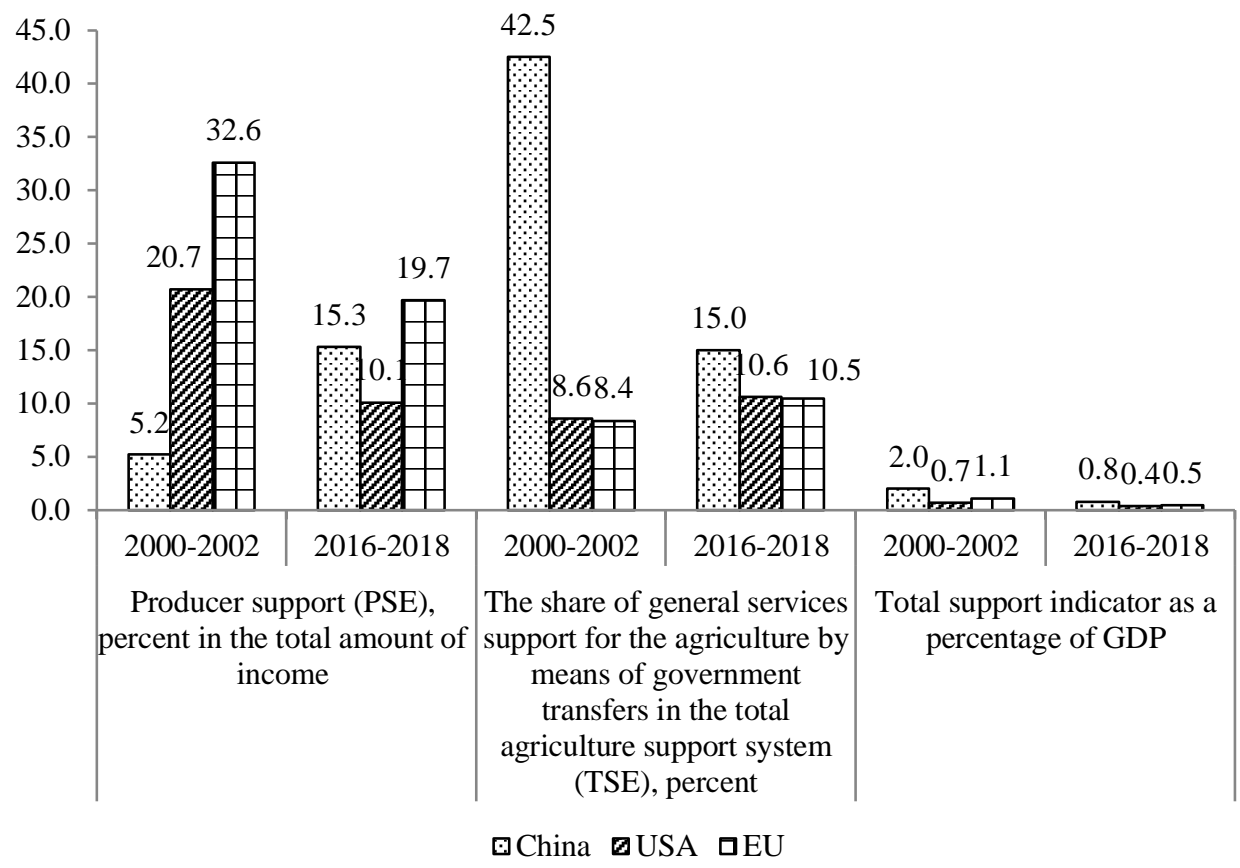

Fig. 1. The structure of agricultural production support in foreign countries (The source: developed by the authors based on the data [2].

For the period 2016-2018 despite the change of the agricultural sector state regulation concept in the EU the state support in the form of direct subsidies, including export subsidies, dominates in the structure of producer support. This index amounted to more than $60.0 \%$ of the total funding, including $85.0 \%$ - "green-box support for farmers" [1, 3].

In China, on the contrary, the index of price protection of producers shows stable positive dynamics due both to the implementation of the tough protectionism policy, despite the country's membership in the WTO, and to the growth rates of national economy and income. In the aggregate, the government spending for producer support tends to increase in absolute and relative terms.

The percentage decrease of direct forms of agricultural commodity producer support in the EU and the US is followed by the increase of indirect support forms, including financing of general services by means of government transfers. This form of support includes green-box support for farmers, such as education and training expenditures covering, control of food quality and security, infrastructure improvement, marketing activity, investment in research and development, etc.

Describing measures of agricultural sector state support in the US, special attention should be paid to the export trend of subsidization, ninefold predominance of "green-box support for farmers" compared with the rest support measures and considerable expenses of budgetary funds for domestic food aid to the disadvantaged population - customer support (CSE) (in the amount of 120 US dollars per person) [4].

In general, the total indicator of agricultural production support (TSE) calculated as a percentage of GDP in accordance with the contemporary agricultural policy concept of agricultural market oversupply tends to decrease during the period 2000-2018.

The lack of the well-managed consistent strategy for the agricultural production development in Russia from the very beginning of economic reforms is marked by unstable 
dynamics of the amount of total state support (Figure 2).

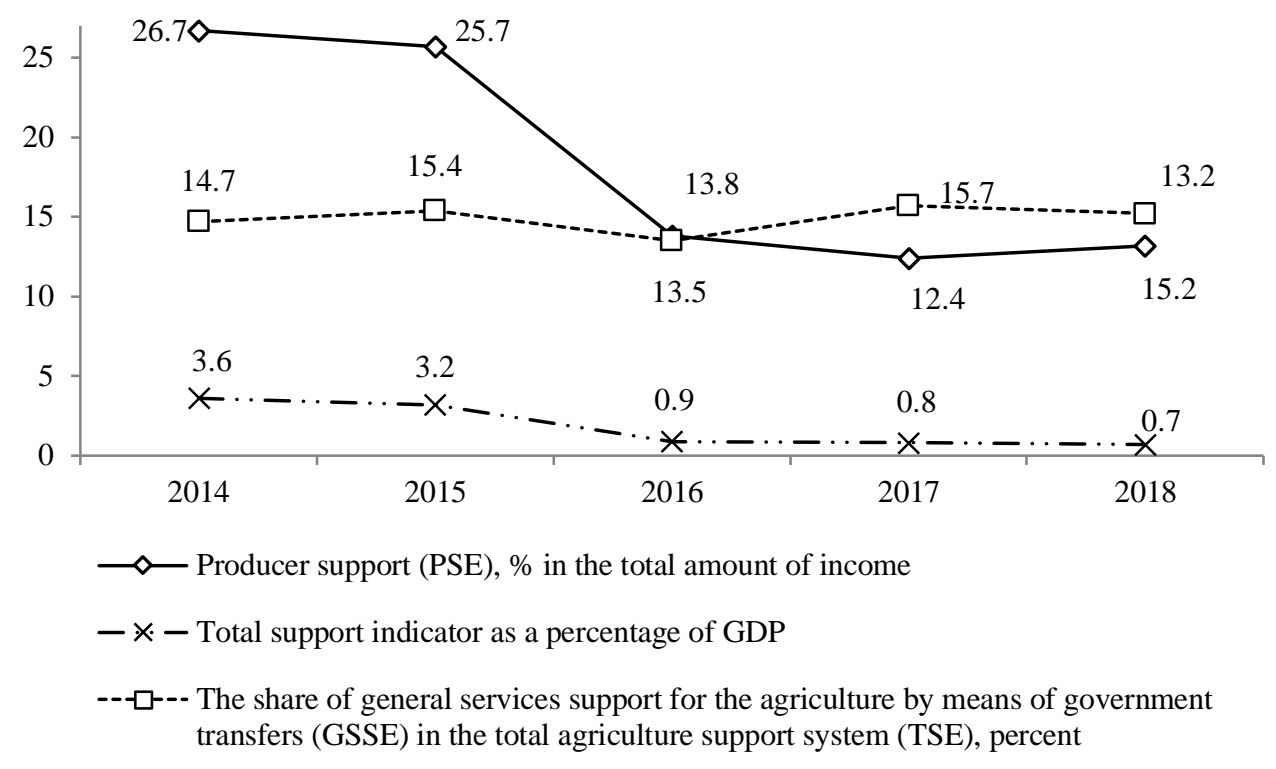

Fig. 2. The structure of agricultural production support in Russia (The source: developed by the authors based on the data [2]).

Over the past decade, Russian policy of state regulation of social and economic development has been passing through dramatic shift. The selection of national priorities, including the national project "Development of agro-industrial complex", transformed into the first sectoral State program for agricultural development for the period 2008-2012, contributed to the determination of goals, targets, planning variables and state obligation for agricultural producer support. All economic sectors are switched to the program-targeted financing since 2013.

The scale of agricultural production state support in Russia shows that the share of federal expenditures for the development of agricultural production varied from $1.97 \%$ in 2008 to $1.1 \%$ in 2017 (Figure 3), while in 1990 this indicator amounted to $23.2 \%$ [4].

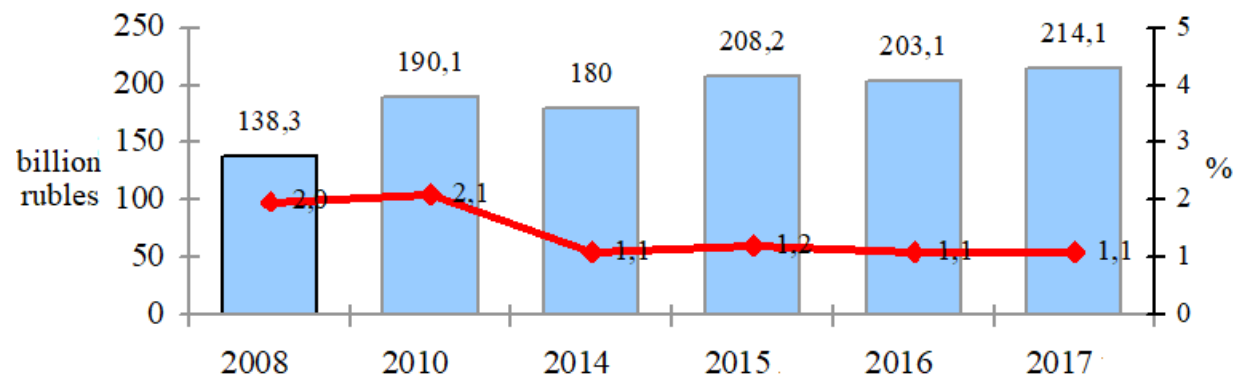

Total federal expenditures for agricultural production, billion rubles

The share of the expenditures for agricultural sector support in the total federal expenditures, $\%$

Fig. 3. The scale of agricultural production state support in Russia (The source: developed by the authors based on the data [5]). 
At the insufficient level of agricultural sector state support only a small part of it was accounted for by agricultural producers. Frequently the indirect support was given to the banking sector and insurance companies, as far as the key direction of the State Program was defined as the reimbursement of credit interest rate, which accounted for up to $80.0 \%$ of subsidies. In addition, the investments were actively used in the fast-growing sectors, including swine rearing and poultry breeding, and other areas were not properly developing $[6,8,7]$.

Therefore, in order to improve the directions of state support, new measures were introduced in the State Program for the period 2013-2020, including "green-box support for crop production income" per hectare of the crop acreage. This "green-box support" is intended to partly reimburse the cost of purchasing fuel, fertilizers and crop protection agents.

Since 2017 the subsidization principles and approaches were updated in the system of agricultural production state support in Russia. Thus, the essential innovations include the consolidation of state support measures on the ground of "united subsidy" for the regions and the soft-window facility [9].

According to the Ministry of Agriculture of the Russian Federation, the "united subsidy" should expand the powers of entities to define priority directions and achieve target indicators of regional programs, increase the efficiency and the use of budgetary funds by agricultural producers.

The new soft-window facility, introduced in Russia in 2017 as part of the RF Government Regulation No. 1528 of 29 December 2016, is based on the application of the principles of consumers demand promotion for farming equipment, similar to those adopted in 2008 for automobile industry. According to the Ministry of Agriculture of Russia, the soft-window facility will make it possible to increase the demand for domestically produced farming equipment, further load the production facilities of factories, create additional employment, increase credit availability for agricultural producers, reduce their cost loading, reorient previously withdrawn current capital to pay the subsidized part of the interest rate for current business and operations financing, which seems to be a significant support for the farmers $[10,11]$.

According to the Regulation, the cost of credit for the end borrower for equipment purchasing is not more than $5.0 \%$ per annum. The state pays compensation to loan institutions for lost earnings caused by servicing of credits to agricultural producers. The subsidy rate for commercial banks is $100.0 \%$ of the key interest of the Bank of Russia. Therewith, the buyer obtains a credit on easy terms by request for the purchase of new equipment produced in the territory of Russian Federation not earlier than the year preceding its sale and not previously used.

It is worth pointing out that in countries, where the biggest global producers of farming equipment are concentrated, the key interests of central banks are much lower than in Russia: in the US it is up to $1.5 \%$, in Canada - up to $1.25 \%$, in the EU - $0 \%$, in Japan minus $0.1 \%$, in Sweden - minus $0.5 \%$ [12].

Since 2018 the Government of the Russian Federation approved five government programs as "pilot" for adoption of project methods, including the State Program for agricultural development for 2013-2020, extending its validity period to 2025 and changing its structure. The new structure of the State Program consists of the project and process (operational) parts, which include, respectively, priority federal and departmental projects as well as corresponding measures (Figure 4). 
State Program "Development of agriculture and regulation of agricultural commodity markets for 2013-2025"

\begin{tabular}{|c|c|}
\hline $\begin{array}{l}\text { PROJECT PART } \\
\text { includes priority federal and departmental } \\
\text { projects: } \\
\text { - departmental project "Development of agro- } \\
\text { based industries enabling fast import } \\
\text { substitution of the main kinds of agricultural } \\
\text { commodities, food and primary products"; } \\
\text { - departmental project "Promotion of } \\
\text { investment activity in the agro-industrial } \\
\text { complex"; } \\
\text { - departmental project "Technical } \\
\text { improvement of the agro-industrial complex"; } \\
\text { - priority project "Export of agricultural } \\
\text { products"; } \\
\text { - Federal Special Purpose Program } \\
\text { "Development of agricultural land melioration } \\
\text { in Russia for 2014-2020"; } \\
\text { - Federal Special Purpose Program } \\
\text { "Sustainable development of rural areas for }\end{array}$ & $\begin{array}{l}\text { PROCESS } \\
\text { (OPERATIONAL) PART } \\
\text { includes directions } \\
\text { (subprograms): } \\
\text { - "Development of melioration of Russian } \\
\text { agricultural lands"; } \\
\text { - "Sustainable development of rural areas"; } \\
\text { - "Management of the state program } \\
\text { execution"; } \\
\text { - Supporting of the common conditions for } \\
\text { agro-based industries operation"; } \\
\text { - "Research and development support of } \\
\text { agro-based industries enhancement"; } \\
\text { - "Development of raw material base for } \\
\text { light industry provision with qualitative } \\
\text { agricultural raw materials (analytic } \\
\text { section)". }\end{array}$ \\
\hline
\end{tabular}

Fig. 4. The structure of the State Program "Development of agriculture and regulation of agricultural commodity markets for 2013-2025" in terms of project methods adoption (developed by the authors based on the research findings).

Fundamental changes of the project methods of agricultural producer state support consist in the following:

- subsidization is introduced for development of priority sectors of agro-industrial complex and maintenance of achievements in all sectors, including "united subsidy", "green box support for crop production income" and subsidies for productivity increase of dairy farming;

- specialization and production capabilities of regions, which are in direct relationship to environmental, economic and infrastructure specifics, determine the choice of priority industries and targets;

- sector subsidy rates are calculated based on the basic standards of production costs;

- budget support is provided to all agricultural business entities which have achieved key performance indicators, regardless of industrywide performance [13, 14].

According to the Ministry of Agriculture, at the moment there are nine priority subsectors of agro-industrial complex development in Russia, including: stimulating the production of white straw and pulse crops, stimulating the oil crop production, stimulating the production of field vegetables, developing winegrowing, stimulating the production of fruit and berry plantations, stimulating the linen flax production, stimulating milk production, developing specialized beef breeding and sheep breeding.

It should be noted that since 2019 the changes of the register of subsidy recipients were introduced in the State Program for development of agriculture and regulation of agricultural commodity markets, providing for the possibility of state support of scientific organizations, professional educational organizations, educational organizations of higher education, which carry out agricultural production, primary and further processing in the process of scientific, research-engineering or educational activities [15].

Beginning from 2020 the new mechanism of subsidy allocation will be in effect in 
Russian agriculture. Changes of the state support will help regions to develop their priority and specific areas, which in the long run will contribute to allocated budget funds efficiency increase.

According to the established rules the state support for "Development of agro-industrial complex sectors", including "united subsidy", "green-box support for crop production income", dairy farming productivity increase will be allocated as part of "Compensative" and "Incentive" subsidies.

The total funding limit for this area in 2020 will be 60.9 billion rubles, including 34 billion rubles for compensative payments and 26.9 billion rubles for incentive payments. During the first stage of new state support mechanism implementation in 2020 the ratio of "compensative" and "incentive" subsidies will be in favour of "compensative", but in the future there incentive payments will prevail over the compensative part [16].

"Compensative" subsidy payments will include funds for agricultural technological works conduction in crop production, support of own milk production, support of livestock farming, support of elite seed production, development of beef farming, development of traditional sub-sectors of crop production and breeding, and also support of agricultural insurance.

The amount of the "compensative" subsidy will be determined on the ground of historical data about regions "proceeding from the share of each region in the total value of indicators across Russian Federation" for 2018, for the "agricultural insurance" area it will be based on the plan for 2020. Budgetary funds limits and weighing coefficients for regions are set for each area of support within the "compensative" subsidy. Herewith, the regions independently choose the directions, volumes and rates of federal budget funds distribution [17].

The "incentive" subsidy will be allocated throughout the regions in accordance with the priority sectors of agro-industrial complex development assigned to them.

Furthermore, incentive budget payments will include subsidies for the development of small businesses, along with support of ten regions with the low level of social and economic development, which were determined on the basis of the average per capita income of the population, unemployment rate, the share of population with substandard income and quote of the investments in fixed assets. According to the Ministry of Agriculture of Russia the "constituent entities of the Russian Federation with the low level of social and economic development" include Republic of Karelia, Republic of Altai, Republic of Tuva, Republic of Adygei, Republic of Kalmykia, Republic of Mari El, Chuvash Republic, Altai Territory, Kurgan and Pskov Region.

The signification coefficients will be applied to define the rate of "incentive" subsidy both for each priority sub-sector of agro-industrial complex, and for each of the indicators.

\section{Conclusion}

The conditions of the new Russian economic reality point to the fact that the key methods of agricultural sector state regulation, including state support, are no longer working. Therefore, there is the need to improve considered updated areas of state support, creating specific background for the state's impact on the country's food safety processes and implementation of the export-oriented agricultural development strategy. Consequently beginning from 2020 the new mechanism of subsidy allocation will be in effect in Russian agriculture. Changes of the state support will help regions to develop their priority and specific areas, which in the long run will contribute to allocated budget funds efficiency increase. 


\section{References}

1. G. Grigoreva, M. Kabanenko, N. Andreeva, IOP Conf. Series: Earth and Environmental Science 274, 012074 (2019) doi:10.1088/1755-1315/274/1/012074

2. A. Battalova, Procedia Economics and Finance 27, 235-239 (2015)

3. D. Pletnev, V. Barkhatov, Procedia - Social and Behavioral Sciences 2217, 185-193 (2016) doi.org/10.1016/j.sbspro.2016.05.105

4. G.N. Ryazanova, IFAC-PapersOnLine $\quad \mathbf{5 2 ( 2 5 ) ,} \quad 225-230 \quad$ (2019) doi.org/10.1016/j.ifacol.2019.12.477

5. E. Nikolaeva, Procedia - Social and Behavioral Sciences 238, 364-373 (2018) doi.org/10.1016/j.sbspro.2018.04.013

6. J. Klomp, Research in International Business and Finance 51, 101073 (2020) doi.org/10.1016/j.ribaf.2019.101073

7. L. Chernykh, Journal of Corporate Finance 17(5), 1237-1253 (2011) doi.org/10.1016/j.jcorpfin.2011.06.009

8. O.V. Isaeva, Regionalnyie agrosistemy: ekonomika i sociologiya 2, 67-76 (2019)

9. O.V. Kirsanova, Naucznoe obozrenie 4, 260-266 (2015)

10. P.O. Skobelev, E.V. Simonova, S.V. Smirnov, D.S. Budaev, G.Yu. Voshchuk, A.L. Morokov, Procedia Computer Science 150, 154-161 (2019) doi.org/10.1016/j.procs.2019.02.029

11. S. Malle, Journal of Eurasian Studies 4(1), 78-99 (2013) doi.org/10.1016/j.euras.2012.07.004

12. S.K. Wegren, Journal of Eurasian Studies 3(2), 193-202 (2012) doi.org/10.1016/j.euras.2012.03.010

13. A.N. Tarasov, M.A. Kholodova, Economics of agricultural and processing enterprises 8, 38-47 (2018)

14. V. Uzun, N. Shagaida, Z. Lerman, Land Use Policy 83, 475-487 (2019) doi.org/10.1016/j.landusepol.2019.02.018

15. A. Chernaya, M. Kabanenko, S. Ugrimova, Conf. Series: Earth and Environmental Science 274, 012073 (2019) doi:10.1088/1755-1315/274/1/012073

16. Y. Griewald, Ecological Economics 151, $1-9 \quad$ (2018) doi.org/10.1016/j.ecolecon.2018.04.026

17. N. Stupak, Environmental Science \& Policy 68, $10-19 \quad$ (2017) doi.org/10.1016/j.envsci.2016.10.003 